\title{
Review
}

\section{Midkine, a heparin-binding cytokine with multiple roles in development, repair and diseases}

\author{
By Takashi Muramatsu*1, $\dagger$
}

(Communicated by Takao SEKIYA, M.J.A.)

\begin{abstract}
Midkine is a heparin-binding cytokine or a growth factor with a molecular weight of $13 \mathrm{kDa}$. Midkine binds to oversulfated structures in heparan sulfate and chondroitin sulfate. The midkine receptor is a molecular complex containing proteoglycans. Midkine promotes migration, survival and other activities of target cells. Midkine has about $50 \%$ sequence identity with pleiotrophin. Mice deficient in both factors exhibit severe abnormalities including female infertility. In adults, midkine is expressed in damaged tissues and involved in the reparative process. It is also involved in inflammatory reactions by promoting the migration of leukocytes, induction of chemokines and suppression of regulatory $\mathrm{T}$ cells. Midkine is expressed in a variety of malignant tumors and promotes their growth and invasion. Midkine appears to be helpful for the treatment of injuries in the heart, brain, spinal cord and retina. Midkine inhibitors are expected to be effective in the treatment of malignancies, rheumatoid arthritis, multiple sclerosis, renal diseases, restenosis, hypertension and adhesion after surgery.
\end{abstract}

Keywords: midkine, pleiotrophin, proteoglycans, cancer, inflammation, repair

\section{Introduction}

Midkine (MK) is a cytokine or a growth factor and belongs to the carbohydrate-binding proteins. ${ }^{1-3)}$ Cytokines and growth factors are classified to structurally-related protein families such as the fibroblast growth factor family. MK is the founding member of a family, which is composed of only two members in humans. The other member is pleiotrophin, also called HB-GAM.4),5)

MK promotes growth, ${ }^{6}$ survival, ${ }^{7)}$ migration ${ }^{8}$ and gene expression ${ }^{9}$ of various target cells. It is involved in reproduction ${ }^{10)}$ and repair, ${ }^{11)}$ and also plays pathological roles in many diseases.

*1 Department of Health Science, Faculty of Psychological and Physical Science, Aichi Gakuin University, Aichi, Japan.

$\dagger$ Correspondence should be addressed: T. Muramatsu, Department of Health Science, Faculty of Psychological and Physical Science, Aichi Gakuin University, 12 Araike, Iwasaki-cho, Nisshin, Aichi 470-0195, Japan (e-mail: tmurama@dpc.agu.ac.jp).

Abbreviations: ALK: anaplastic lymphoma kinase; LRP: low density lipoprotein receptor-related protein; MFP: medial floor plate; MK: midkine; PTN: pleiotrophin; PTP $\zeta$ : Receptor-like protein tyrosine phosphatase- $\zeta$.
MK is attracting much attention in relation to the treatment of diseases. MK inhibitors are expected to be useful in treating cancer, ${ }^{12)}$ rheumatoid arthritis, ${ }^{13)}$ multiple screlosis, ${ }^{14)}$ hypertension, ${ }^{15}$ ) renal diseases ${ }^{9}$ ) etc., while MK itself is promising for the treatment of ischemic brain injury, ${ }^{11)}$ retinal degeneration ${ }^{16)}$ and heart failure. ${ }^{17)}$

We found MK as a product of a gene, whose expression was induced at the early stages of the retinoic acid-induced differentiation of teratocarcinoma stem cells. ${ }^{18)}$ PTN was found as a protein with neuritepromoting activity ${ }^{19)}$ or as a factor with growthpromoting activity to fibroblasts. ${ }^{20)}$ We reported full protein sequence of MK in 1990, ${ }^{21)}$ and the sequence of PTN was reported subsequently ${ }^{22), 23)}$ : MK and PTN were revealed to have about $50 \%$ sequence identity.

The precisely controlled manner of MK expression during embryogenesis ${ }^{24}$ ) and unique features of the protein structure ${ }^{21)}$ were sufficient to convince us of the importance of the molecule, and we initiated systematic studies. Glycosaminoglycan-recognizing activity of $\mathrm{MK}^{25}$ ) was an additional factor tempted me to study MK extensively, since my long term 


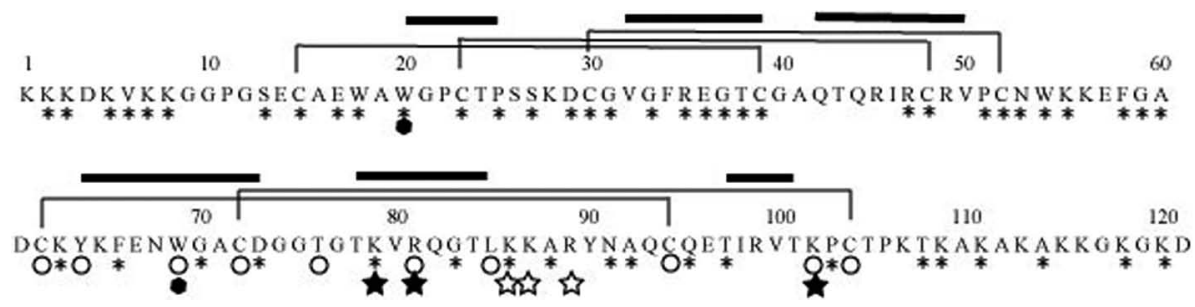

Fig. 1. Primary structure of human MK. *, amino acids conserved between human MK and PTN; O, amino acids conserved among Drosophila miples, human MK and human PTN; - tryptophan conserved in the thrombospondin superfamily; $\star \succsim$,

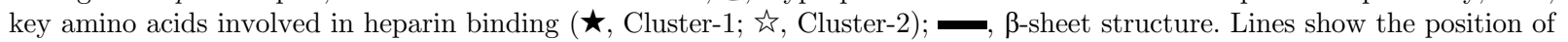
disulfide linkages.

Trisulfated Unit

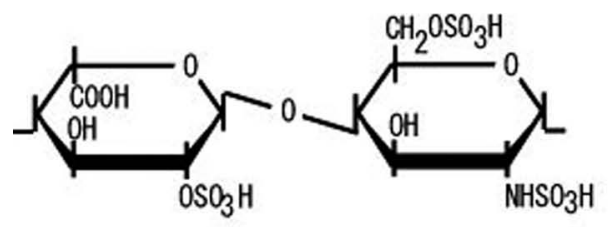

MK C-domain

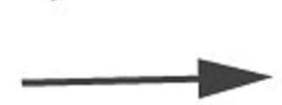

\author{
(2)
}

E Unit

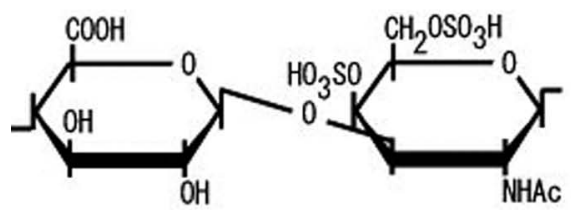

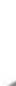

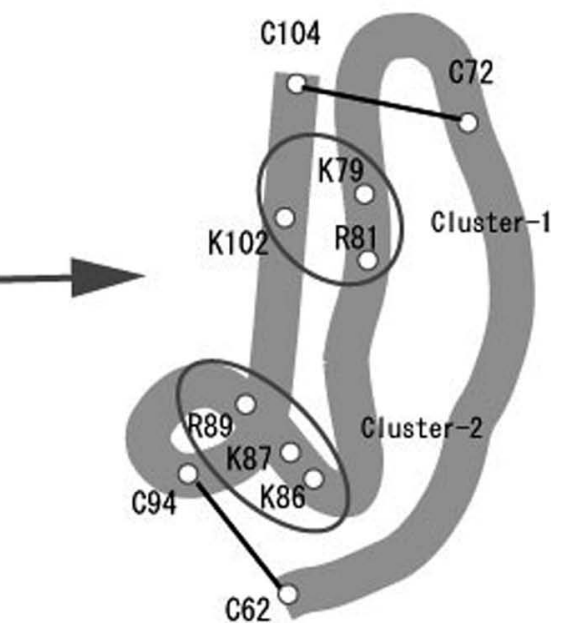

Fig. 2. Binding of heparan sulfate trisulfated unit and chondroitin sulfate E unit to C-domain of human MK. Two heparinbinding sites in the C-domain are encircled.

interest has been the physiological significance of carbohydrate recognition at the cell-surface. ${ }^{26)}$

Here I summarize the information currently available on MK. The details of earlier findings were described in previous reviews. ${ }^{1), 2)}$

\section{Protein and gene}

MK is rich in basic amino acids and cysteine, and has a molecular weight of about $13 \mathrm{kDa}^{21}$ ) (Fig. 1). MK is conserved from humans to fish, human MK and mouse MK having $87 \%$ sequence identity. ${ }^{1), 27)}$ Drosophila melanogaster lacks MK, but has miple-1 and miple-2, which have a motif common to MK and $\mathrm{PTN}^{28)}$ (Fig. 1).

MK is mainly composed of two domains held by disulfide linkages. ${ }^{29)}$ The more C-terminally located domain (C-domain) has principal heparin-binding activity and retains some of the physiological activities. ${ }^{30)}$ Each domain of MK has weak homology to the thrombospondin Type I repeat ${ }^{31)}$ (Fig. 1). Both domains are composed of three antiparallel $\beta$-sheets as revealed by NMR spectroscopy. ${ }^{32)}$ The C-domain has two clusters of basic amino acids (Cluster-1 and -2 ), which are required for heparin-binding 32 -34) (Figs. 1, 2). Among them, Cluster-1 is the evolutionarily conserved one (Fig. 1). MK tends to form dimers via spontaneous association, and the dimers are stabilized by crosslinking with transglutaminase. ${ }^{35)}$ Dimerization appears to be required for MK activity. ${ }^{35)}$ After dimerization, Cluster-2 may form a fused and strong binding site. ${ }^{32)}$

MK is produced in recombinant forms in $\mathrm{L}$ cells, ${ }^{36)}$ baculovirus, ${ }^{37)}$ yeast, ${ }^{38)}$ and Escherichia coli, ${ }^{39)}$ and has also been synthesized chemically. ${ }^{40)}$ During 
Table 1. Actions of MK to cultured cells

\begin{tabular}{|c|c|}
\hline Promoted cellular activities & Target cells \\
\hline \multicolumn{2}{|l|}{ Soluble $M K$} \\
\hline Growth & Fibroblasts, ${ }^{36)}$ keratinocytes, ${ }^{151)}$ tumor cells ${ }^{6), 12)}$ \\
\hline Survival & Embryonic neurons ${ }^{7), 51)-53)}$ \\
\hline Contraction of collagen gels & Fibroblasts ${ }^{152)}$ \\
\hline Synthesis of extracellular matrices & Fibroblasts ${ }^{153)}$ \\
\hline Synthesis of cytokines & Endothelial cells, ${ }^{54)}$ renal epithelial cells 9 ) \\
\hline Fibrinolytic activity & Endothelial cells ${ }^{154)}$ \\
\hline Migration & Neutrophils ${ }^{55)}$ \\
\hline \multicolumn{2}{|l|}{ Substratum-bound $M K$} \\
\hline Growth & Neural precursor cells ${ }^{58)}$ \\
\hline Survival & Neural precursor cells ${ }^{58)}$ \\
\hline Extension of neurite or processes & Embryonic neurons, ${ }^{36), 37)}$ oligodendrocyte precursor-like cells ${ }^{66)}$ \\
\hline Migration & Neurons, ${ }^{8)}$ osteoblast-like cells, ${ }^{57)}$ neutrophils,${ }^{55)}$ macrophages ${ }^{56)}$ \\
\hline Clustering of acetylcholine receptors & Myoblasts ${ }^{85)}$ \\
\hline
\end{tabular}

the chemical synthesis, MK with aberrant disulfide bridges was rigorously removed. MK is an adhesive protein, and care is needed to avoid absorption to vessels as explained elsewhere. ${ }^{41)}$

The human MK gene $(M D K)$ is present on chromosome 11 at p11.2 42 ) between the diacylglycerol kinase $\mathrm{z}$ gene and muscarnic acetylcholine receptor 4 gene, ${ }^{1)}$ while the mouse counterpart $(M d k)$ is on chromosome 2.43) $M D K$ and $M d k$ encompass $2 \mathrm{~kb}$ and have 4 exons. ${ }^{44), 45)}$

MK expression is induced by retinoic acid, and the promoter region has a functional retinoic acidresponsive element. ${ }^{46)}$ Glucocorticoid suppresses MK expression through its nuclear receptor. ${ }^{47)}$ The promoter region also has a binding site for $\mathrm{WT}-1$, the product of the Wilms' tumor suppressor gene. ${ }^{48)}$ Furthermore, hypoxia induces MK expression through the binding of hypoxia inducible factor- $1 \alpha$ (HIF-1 $\alpha)$ to a hypoxia responsive element in the MK promoter. ${ }^{49)}$ MK expression is strictly controlled both spatially and temporally during embryogenesis. ${ }^{24), 50)}$ Generally, MK is most intensely expressed during midgestation, while the expression is weak or absent in the majority of adult tissues. ${ }^{1), 24)}$

\section{In vitro activities and mechanism of action}

MK exhibits various activities in vitro (Table 1 ). For example, soluble MK promotes the growth of fibroblasts, ${ }^{36)}$ survival of embryonic neurons ${ }^{1), 7), 51)-53)}$ and expression of chemokines. ${ }^{9), 54)}$ The substratum-bound form enhances outgrowth of neurites ${ }^{6), 36), 37)}$ and migration of neutrophils, ${ }^{55)}$ macrophages, ${ }^{56)}$ embryonic neurons ${ }^{8)}$ and osteoblast-like cells. ${ }^{57)}$ Occasionally, substratum-bound MK shows stronger activity than the soluble form. For example, the growth and survival of neural precursor cells is promoted only by substratum-bound MK. ${ }^{58)}$ Probably, MK in the tissue is delivered to target cells as a matrix-bound form. Inhibition of MK-dependent migration of UMR106 osteoblast-like cells is frequently employed in the screening of MK inhibitors (Matsui et al., unpublished obsevations).

MK is inhibited by heparin, a sulfated glycosaminoglycan. Therefore it is likely that recognition of glycosaminoglycans in proteoglycans is essential for MK activities. Oligomers of heparan sulfate trisulfated units and those of chondroitin sulfate E units have been identified as structures required for strong binding to $\mathrm{MK}^{41), 59)-61)}$ (Fig. 2). The affinitiy of the two structures for MK is considered similar, based on behavior upon MK-affinity chromatography, surface plasmon resonance spectroscopy, and inhibition of neurite outgrowth. ${ }^{41)}$ The presence of these highaffinity binding structures in the embryonic brain of mice has been confirmed by an analysis of glycosaminoglycans synthesized by the cells. ${ }^{61}$ )

Receptor-like protein tyrosine phosphatase- $\zeta$ $(\mathrm{PTP} \zeta),{ }^{8)}$ syndecans, ${ }^{50), 62), 63)}$ glypican-2, ${ }^{64)}$ PG-M/ versican $^{65)}$ and neuroglycan $\mathrm{C}^{66}$ are proteoglycans with strong affinity for MK. Among them, $\mathrm{PTP} \zeta$, a 


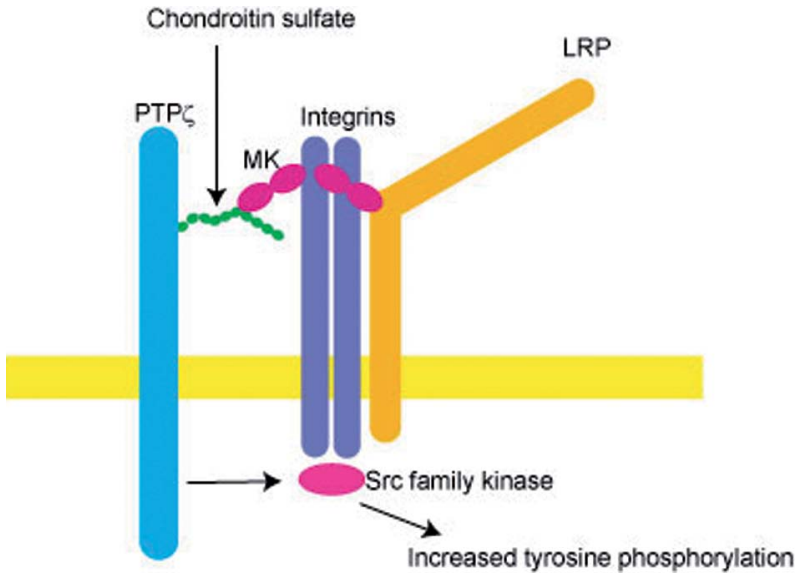

Fig. 3. A proposed model of MK action. MK, which acts as a dimer, binds to components of the receptor including glycosaminoglycan chains, and promotes the formation of the receptor complex. When an MK dimer binds to an integrin and the chondroitin sulfate chain of PTP $\zeta$, the cytoplasmic phosphatase domain of PTP $\zeta$ becomes closer to the cytoplasmic domain of the integrin, resulting in an increase in the tyrosine phosphorylation of key signaling molecules.

chondroitin sulfate proteoglycan, is an established component of the MK receptor. $\mathrm{PTP} \zeta$ binds to MK with a $\mathrm{Kd}$ of $0.56 \mathrm{nM}$, which decreases to $8.8 \mathrm{nM}$ after the removal of chondroitin sulfate chains. ${ }^{8)}$

Analyses of MK-binding proteins from embryonic brains have revealed that low density lipoprotein receptor-related protein (LRP), ${ }^{67)} \alpha_{4} \beta_{1}$-integrin and $\alpha_{6} \beta_{1}$-integrin ${ }^{68)}$ also serve as MK receptors. These proteins and $\mathrm{PTP} \zeta$ form a receptor complex, and MK promotes this process. ${ }^{68)}$ A model of MK action through the receptor complex is shown in Fig. 3. By the complex formation, $\mathrm{PTP} \zeta$ and the downstream signaling systems of integrins might come to be located close together.

After MK stimulation, intracellular tyrosine phosphorylation increases. Inhibitors of Src family kinases hinder MK activities, indicating the importance of these kinases in signaling. ${ }^{57)}$ After MK action, $\mathrm{PTP} \zeta$ may act on a tyrosine phosphate residue, which locks Src kinase in an inactive state. Removal of the phosphate residue will lead to the activation of Src, as in the case of PTN signaling. ${ }^{69)}$ Alternatively, MK stimulates dimerization of PTP $\zeta$, leading to inactivation of $\mathrm{PTP} \zeta$, which might compete with Src. ${ }^{70)}$ An observation that vanadate, an inhibitor of $\mathrm{PTP} \zeta$, inhibits $\mathrm{MK}^{57)}$ appears to favor the former view.

Increased tyrosine phosphorylation of paxillin accompanying MK action occurs in case of cell mi- gration of osteoblast-like cells. ${ }^{68)}$ Upon promotion of survival, activation of PI3 kinase and MAP kinase takes place, followed by suppression of caspases. ${ }^{7), 71)}$

For promotion of the migration and invasion of human head and neck squamous cell carcinoma cells, MK binds to $\alpha_{6} \beta_{1}$-integrin and tetraspanin, and induces tyrosine phosphorylation of FAK followed by activation of paxillin and STAT1 $\alpha$ pathway. ${ }^{72)}$ Phosphorylation of STAT3 by MK stimulates the proliferation of postconfluent 3T3-L1 cells, leading to adipogenesis. ${ }^{73)}$ Notch2 is a receptor for MK upon epithelial-mesenchymal transition in immortalized keratinocytes, acting through the Jak2/STAT3 system. ${ }^{74)}$ On the other hand, STAT5 phosphorylation is suppressed by MK. ${ }^{14}$

Anaplastic lymphoma kinase (ALK) has been proposed to be an MK receptor. ${ }^{75)}$ ALK also forms complex with LRP and integrins, suggesting that it is recruited to the receptor complex and plays roles in MK signaling (Muramatsu, H. et al., unpublished observations). After activation by MK, ALK phosphorylates insulin receptor substrate-1, activates MAP kinase and PI3 kinase and causes transcriptional activation of $\mathrm{NF \kappa B} .{ }^{76}$ )

Neuroglycan C serves as an MK receptor upon process extension in oligodendrocyte precursor-like cells. ${ }^{66)}$ Neuroglycan $\mathrm{C}$ also functions in a receptor complex (Ichihara et al., unpublished observations). In addition to various cell-surface proteins mentioned above, neuropilin-1 was identified in MKbinding proteins from UMR106 osteoblast-like cells (Muramatsu, H. et al., unpublished observations).

MK binds to nucleolin, a nuclear protein which is also located at the cell surface and functions as a shuttle to the nucleus. ${ }^{39)}$ LRP, a component of the MK receptor, serves to internalize the bound MK. ${ }^{77)}$ After this internalization, cytoplasmic MK is transferred to the nucleus by nucleolin ${ }^{77)}$ and by lamininbinding protein precursor, ${ }^{78)}$ and the transportation is important to cell survival induced by MK. ${ }^{77)}$ Thus, MK might also act within the nucleus. Indeed, MK transferred to the nucleolus is involved in the synthesis of ribosomal RNA at the place. ${ }^{79)}$ Translation initiation factor (eIF3) is also an MK-binding protein in the embryonic brain, the physiological significance of which remains to be established (Muramatsu, H. et al., unpublished observations).

\section{Neurogenesis}

During midgestation period, MK expression is intense in neural tissue, epithelial tissue in the pro- 
cess of epithelial-mesenchymal interactions and mesoderm undergoing remodeling. ${ }^{24), 50)}$ In each of these tissues, further studies have revealed the developmental significance of MK activity.

During the development of Xenopus laevis, MK is found in the neural anlagen and strongly expressed in the brain and spinal cord. When MK mRNA is injected into the dorsal vegetal region of 8-cell embryos, neural tissues enlarge abnormally. The excised ectoderm from this embryo is enhanced in development of anterior neural tissue after activin treatment, and is suppressed in mesoderm induction as compared to the normal ectoderm. ${ }^{80)}$

The role of MK in the initial stages of neurogenesis has been elucidated in the zebrafish, which has two MK molecules (Mdka and Mdkb) as a result of gene duplication. Mdka is expressed in the paraxial mesoderm and is involved in the formation of the medial floor plate (MFP) in the adjacent neural tube. MFP organizes the specification of neurons and outgrowth of axons in the ventral spinal cord. Overexpression of Mdka results in an enlargement of the MFP and reduction in the size of the notochord, and downregulation of Mdka expression results in a defective MFP and in increased cell density of the notochord. ${ }^{81)}$ Mdka appears to promote the growth and survival of MFP progenitors, and the increased number of MFP cells probably explains the reduction in size of the notochord. On the other hand, overexpression and knockdown experiments have indicated that Mdkb expressed in the neural plate is required for the earliest steps of cell specification at the neural plate border and is essential for the development of neural crest cells and sensory neurons. ${ }^{82}$ )

In the developing cortex of mice and rats, MK expression is intense in the basal layer, which is composed of proliferating neural precursor cells including neural stem cells. ${ }^{24), 83)}$ Radial glial processes are extended structures derived from neural stem cells, and differentiated neurons migrate externally along these processes. MK is also strongly expressed in radial glial processes, and is a good immunohistochemical marker of the processes. ${ }^{83), 84)}$ An in vitro study has shown that MK enhances the growth and survival of neural precursor cells without inhibiting their differentiation capability. ${ }^{58)}$ This finding provides a cell biological basis to MK activities found in Xenopus laevis. In addition, MK secreted by the neurites of embryonic neurons induces clustering of acetylcholine receptors on myoblasts, suggesting that MK is involved in the formation of synapses. ${ }^{85}$ )

In spite of important roles of MK in neurogenesis, mice deficient in $M d k$ exhibit normal phenotypes in overall neural functions. ${ }^{86)}$ However, in depth analysis of the deficient mice revealed deficits in specific neural functions. These mice are in a hypodopaminergic state in terms of levels of dopamine and its receptors, with defects related to dopamine function (prepulse inhibition). ${ }^{87)}$ Furthermore, mice deficient in Mdk or Ptn exhibit a moderate auditory deficit, while mice deficient in both show a severer phenotype. ${ }^{88)}$ Although the defect in the single knockout mice may be due to deficit in sensory neurons, the severe defect in the double knockout could principally be caused by abnormalities in the cochlea, including a drastic decrease in $\beta$-tectorin expression. In any event, it is likely that the loss of MK is usually compensated for by other molecules during mouse neurogenesis, but in certain regions it is not compensated leading to expression of phenotypes. Detailed analyses of MK deficient mice are expected to reveal more neurological phenotypes.

\section{Epithelial-mesenchymal interactions}

The role of MK in epithelial-mesenchymal interaction has been studied using an artificial blood vessel model, in which vascular endothelial cells from the human umbilical cord are cultured on human aortic smooth muscle cells. ${ }^{54)}$ The endothelial cells secrete MK, which acts on smooth muscle cells and induces production of factors including IL8. IL8 then acts on the endothelial cells and promotes their growth. Thus, MK plays a key role in the interaction between epithelial cells and mesenchymal cells. In the in vitro differentiation system of the lung germ, MK produced by epithelial tissue stimulates the development of mesenchymal tissue. ${ }^{89)}$ The development of tooth germ in vitro is inhibited by anti-MK antibody. ${ }^{90)}$ In this system, MK appears to suppress excessive activity of BMP-2. Furthermore, MK which is expressed in lung epithelial cells causes vascular remodeling in the organ. ${ }^{49}$ ) MK is also involved in the epithelial-mesenchymal transition of tumor cells. ${ }^{74)}$

In terms of the remodeling of mesenchyme, MK has been identified as an autocrine factor that induces adipocyte formation from 3T3-L1 cells. ${ }^{73)}$ Furthermore, transfection of MKcDNA to chondrogenic cells enhances chondrogenesis. ${ }^{91)}$ 
Table 2. Overexpression of MK in human tumors

\begin{tabular}{|c|c|c|c|}
\hline Tumors & General & $\begin{array}{l}\text { Relation to } \\
\text { prognosis }\end{array}$ & $\begin{array}{l}\text { Target of } \\
\text { therapy }\end{array}$ \\
\hline Oral squamous cell carcinoma & Ruan et al. 2007 ${ }^{155)}$ & Ruan et al. 2007 ${ }^{155)}$ & \\
\hline Esophageal carcinoma & Aridome et al. $1995^{95)}$ & & \\
\hline Gastric carcinoma & Aridome et al. 1995 ${ }^{95)}$ & & \\
\hline Colon carcinoma & Aridome et al. 199595) & & Takei et al. 2001'12) \\
\hline Hepatocellular carcinoma & Aridome et al. $1995^{95)}$ & & Dai et al. $2009^{124)}$ \\
\hline Pancreatic head carcinoma & Maeda et al. $2007^{156)}$ & Maeda et al. 2007 ${ }^{156)}$ & \\
\hline Lung carcinoma & Garver et al. 199396) & & \\
\hline Urinary bladder carcinoma & O'Brien et al. $1996^{97)}$ & O'Brien et al. 1996 & \\
\hline Prostate carcinoma & Konishi et al. 199998) & Konishi et al., 199998) & Takei et al. 2006 ${ }^{122)}$ \\
\hline Breast carcinoma & Garver et al. 1994'157) & & \\
\hline Uterine carcinoma & $\begin{array}{l}\text { Moon et al. } 2003,{ }^{158)} \\
\text { Tanabe et al. } 2008^{159)}\end{array}$ & Tanabe et al. 2008 ${ }^{159)}$ & Tanabe et al. 2008 ${ }^{159)}$ \\
\hline Ovarian carcinoma & Nakanishi et al. $1997^{160)}$ & & \\
\hline Osteosarcoma & Maehara et al. 2007 25$)$ & & Maehara et al. 2007 ${ }^{125)}$ \\
\hline Soft tissue sarcoma & Jin et al. 2008 ${ }^{161)}$ & & Jin et al. 2008 161$)$ \\
\hline Neuroblastoma & Nakagawara et al. 199599) & Nakagawara et al. 199599) & \\
\hline Astrocytoma & Mishima et al. 1997100) & Mishima et al. $1997^{100)}$ & \\
\hline Meningioma & Tong et al. 2007 ${ }^{162)}$ & & \\
\hline $\begin{array}{l}\text { Childhood B-precursor acute } \\
\text { lymphoblastic leukemia }\end{array}$ & Hidaka et al. 2007 ${ }^{163)}$ & & \\
\hline Wilms' tumor & Tsutsui et al. 199394) & & \\
\hline $\begin{array}{l}\text { Malignant peripheral } \\
\text { nerve sheath tumor }\end{array}$ & Mashour et al. 2001 105) & & \\
\hline
\end{tabular}

\section{Reproduction}

In spite of various roles of MK in developmental processes, MK-deficient mice are born without major defects. ${ }^{86)}$ The same is true for mice deficient in PTN. However, mice deficient in both were born with $1 / 3$ of the frequency expected by Mendelian segregation, ${ }^{10)}$ were small in size ${ }^{10)}$ and about $50 \%$ died before 4 weeks (Muramatsu, H. et al., unpublished observations). Thus, MK and PTN play important roles in development, and compensate for each other. Furthermore, the double knockout mice exhibited female infertility: after repeated mating with wild-type males, $79 \%$ of the double-deficient females remained sterile. ${ }^{10)}$ Defects in follicular maturation, an altered estrous cycle and vaginal malformation have been found to be the basis of the infertility.
Among them, the defects in follicular maturation appear to be the principal cause; MK and PTN are concluded to be important in follicular maturation. ${ }^{10)}$

The efficiency with which in vitro fertilized bovine embryos develop to the blastocyst stage is increased by adding MK to the culture medium. ${ }^{92)}$ This effect of MK is mediated by cumulus cells surrounding oocytes. MK acts on cumulus cells to help them survive and secrete factors acting on oocytes. ${ }^{93)}$ This MK activity has practical importance. Furthermore, a similar mechanism can be considered for the actions of MK and PTN to promote follicular maturation.

\section{Cancer}

MK is overexpressed in many malignant tumors of humans (Table 2),1),94) including hepatocellular 
carcinoma,${ }^{95)}$ gastric carcinoma,${ }^{95)}$ colon carcinoma,${ }^{95}$ lung carcinoma, ${ }^{96)}$ urinary bladder carcinoma, ${ }^{97)}$ prostate carcinoma, ${ }^{98)}$ neuroblastoma ${ }^{99}$ ) and astrocytoma. ${ }^{100)}$ Overexpression is observed in about $80 \%$ cases in respective tumors. ${ }^{1)}$ Furthermore, patients with high MK expression in the tumor frequently have a worse prognosis than those with low MK expression (Table 2). ${ }^{1,97)-100)} \mathrm{MK}$ is expected to contribute to tumor invasion by promoting growth, survival and migration of tumors and by promoting angiogenesis. Indeed, transfection with MK cDNA results in malignant transformation of NIH 3T3 cells. ${ }^{101)}$ Furthermore, $M D K$ has been identified to be the gene, overexpression of which is most closely correlated with resistance to chemotherapeutics in human gastric cancer cell lines. ${ }^{102)} \mathrm{MK}$ has been also shown to be a mediator of chemotherapy resistance to neighboring cells. ${ }^{103)}$ AcylCoA synthetase 5 is frequently overexpressed in malignant gliomas and contributes to cell survival under extracellular acidosis. Overexpression of the enzyme leads to increased expression of MK, which is partly responsible for the effect of the enzyme. ${ }^{104)}$

The induction of MK in various tumors is probably mediated by hypoxic conditions in the tumor. ${ }^{49)}$ Loss of function of WT1, Wilms' tumor suppressor gene, appears to be the cause of high levels of MK expression in Wilms' tumor, ${ }^{94)}$ since a functional WT1 binding site is present in the MK promoter. ${ }^{48)}$ Oncogenesis due to loss of function of WT1 is likely to involve the induction of MK expression. Furthermore MK is overexpressed in malignant peripheral nerve sheath tumor, based on a lack of function of NF1, another tumor suppressor gene. ${ }^{105)}$

Serum MK levels can be measured with a sandwich enzyme-linked immunoassay. ${ }^{106), 107)}$ The levels are increased in patients with cancer, ${ }^{106)-108)}$ rheumatoid arthritis ${ }^{13)}$ and Alzheimer's disease. ${ }^{109)}$ Because of the distinct clinical features of these diseases, MK is expected to be helpful in the screening of cancer. ${ }^{106), 107), 110)-113)}$ MK levels are not increased in the cases of viral hepatitis, ${ }^{110)}$ with a few exceptions, in which hepatocellular carcinoma developed later (Salama et al., unpublished observations). Patients with high MK serum levels had a poor prognosis in cases of esophageal carcinoma ${ }^{111)}$ and neuroblastoma. ${ }^{114), 115)}$ For large scale screening, a combination of two monoclonal antibodies and usage of beads and an automated system appear to be especially helpful. ${ }^{116)}$ Because of its elevated levels even early on, irrespective of $\alpha$-fetoprotein levels, MK is considered to be helpful in detection of $\alpha$-fetoproteinnegative hepatocellular carcinoma. ${ }^{12)}$ Further information is provided in a previous review. ${ }^{108)}$

In terms of cancer detection, a truncated MK in which exon 3 is skipped by alternative splicing may also be helpful. ${ }^{117)}$ In certain carcinomas such as colon carcinoma, a truncated MK protein is expressed only in tumor tissue, especially in metastasized lymph nodes. ${ }^{177)-119)}$ Although the truncated form was initially detected as mRNA, subsequent study revealed the truncated protein by using a specific antibody. ${ }^{120)}$ Truncated MK can also transform fibroblasts. ${ }^{121)}$

The involvement of MK in tumor progression implies that inhibition of the synthesis or action of MK will contribute to cancer therapy. Indeed, an antisense oligoDNA to MK inhibits the growth of mouse colorectal carcinoma cells in culture, ${ }^{12)}$ most probably by down-regulating intracellular tyrosine phosphorylation as mentioned in the previous section. Furthermore the antisense oligoDNA suppresses the growth of the tumor in nude mice. The delivery of antisense oligoDNA into pregrown tumors has been achieved with the aid of atellocollagen. ${ }^{12)}$ siRNA to human MK enhances the growth inhibitory effect of pacritaxel on human prostate carcinoma cells grown in nude mice. ${ }^{122)}$ It is noted that inhibition of the synthesis of human MK had less of an effect on tumor growth than that of mouse MK. This is probably because even after inhibition of the synthesis of human MK, mouse MK provided by the host supports the growth of the xenografted tumor. Indeed, lung metastasis of an MK-negative tumor is less severe in MK-deficient mice than in wild-type mice. ${ }^{123)}$ The growth of hepatocellular carcinoma in mice is inhibited by antisense oligoDNA to MK delivered by nanoparticles. ${ }^{124)}$

Although polyclonal anti-MK antibodies inhibit the growth of tumor cells in vitro, ${ }^{6,125)}$ many monoclonal antibodies to MK do not have a strong effect, probably because not only extracellular MK, but also intracellular MK contributes to tumor growth, and only a population of anti-MK is able to inhibit intracellular MK. Aptamers to MK did not exhibit significant growth inhibitory effects to tumor cells either. A promising candidate to inhibit MK is a low molecular weight compound. After in silico screening we found that some trifluoro compounds inhibited MKdependent migration of osteoblast-like cells without significant cytotoxic effects (Muramatsu, T. et al., 
unpublished results). Peptide fragments of MK receptors such as LRP ${ }^{126)}$ and integrins (Muramatsu, T. et al., unpublished observations) are also promising. siRNA and antisense oligoDNA to MK have already demonstrated potent inhibitory effects on tumor growth in vivo. Once delivery methods to distant metastatic nests are developed, these agents will become efficient therapeutics to inhibit tumor invasion.

Preferential expression of toxic genes in cancer cells with the help of the MK promoter is also promising as an aid in cancer therapy. ${ }^{127)-130)}$ The MK promoter fused with thymidine kinase gene is especially helpful in adenovirus-mediated gene transfer followed by ganciclovir treatment. ${ }^{128}$ ) Since the MK promoter cannot act in the liver, its use overcomes one major problem in the regime, namely liver toxicity.

\section{Inflammation and repair}

MK expression is induced in damaged tissues, especially after ischemia in blood vessels, ${ }^{56}$ ) the brain cortex ${ }^{131)}$ and the myocardium, ${ }^{17)}$ and exhibits two effects, an enhancement of inflammation and a promotion of survival and repair. Thus, MK is either beneficial or harmful to the injured tissue, depending on its origin. Phenotypes of MK-deficient mice have revealed the role of MK in a pathological state. As an example, upon partial hepatectomy, the remaining liver of MK-deficient mice exhibits less inflammation than that of wild-type mice. However, the growth of the liver is also less extensive in the deficient mice, and as a whole MK-deficiency hinders liver regeneration. ${ }^{132)}$

MK enhances inflammation by promoting the migration of inflammatory leukocytes, ${ }^{9), 55), 56) ~ i n d u c-~}$ ing synthesis of chemokines ${ }^{9}$ ) and suppressing the increase of regulatory $\mathrm{T}$ cells. ${ }^{14)}$ Upon ischemic injury to blood vessels, MK recruits inflammatory leukocytes, which secrete factors promoting the migration of smooth muscle cells and trigger the formation of neointima. ${ }^{56)}$ This neointima formation, which is a model of restenosis after balloon therapy of infarcted coronary vessels, is less extensive in MK-deficient mice than in wild-type mice. ${ }^{56)}$ MK deficiency also has beneficial effects on antibody-induced arthritis (a model of rheumatoid arthritis), ${ }^{13}$ experimental autoimmune encephalitis (a model of multiple sclerosis), ${ }^{14)}$ adhesion after surgery ${ }^{133)}$ and nephritis, which is caused either by ischemia, ${ }^{9)}$ exposure to chemo- therapeutics ${ }^{134)}$ or diabetes. ${ }^{135)}$ The MK-deficient mice used in these experiments were repeatedly backcrossed to C57BL/6 mice so that both mice were in a syngenic state. That the genes flanking $M d k$ were not altered in the deficient mice was confirmed by sequencing (unpublished observations).

In the above-mentioned diseases, MK inhibitors are candidates for therapeutics. siRNAs, antisense oligoDNAs and aptamers to MK have already proved effective in experimental models (Table 3). Notable examples are the treatment of nephritis with an antisense oligoDNA to $\mathrm{MK},{ }^{136}$ ) of neointima formation with an siRNA to $\mathrm{MK}^{137)}$ and of experimental autoimmune encephalitis using an RNA aptamer to MK. ${ }^{14)}$ MK inhibitors might be also effective in the treatment of endometriosis, because of the possible involvement of MK in the disease. ${ }^{138)}$

MK is a regulator of the renin-angiotensin system. ${ }^{15), 139)}$ Hypertension is induced by $5 / 6$ nephrectomy in wild-type mice, but not significantly in MKdeficient mice. ${ }^{15)}$ Further studies have revealed that MK is expressed in the lung after 5/6 nephrectomy, and induces the expression of angiotensin-converting enzyme in microvascular endothelial cells. ${ }^{15}$ ) MK appears to be a key molecule causing hypertension upon chronic nephritis. Thus, there is a possibility that MK inhibitors become useful for the treatment of hypertension. MK is also known to suppress catecholamine biosynthesis in the aorta, but not in other tissues. ${ }^{140)}$

The role of MK in the reparative process was first demonstrated in the retina. Light-induced retinal degeneration is suppressed by the injection of MK into the subretinal region. ${ }^{16)}$ Injection of MK into the brain ventricle delays the onset of the death of hippocampal neurons after ischemia. ${ }^{11)}$ Transfection and expression of MK is also effective. ${ }^{141)}$ Both degeneration and regeneration of injured peripheral nerve are delayed in $M d k$-deficient mice compared to wild-type mice. ${ }^{142)}$ After ischemia and reperfusion of the heart, more $M d k$-deficient mice die due to heart failure than wild-type mice. ${ }^{17)}$ Delivery of MK into the heart substantially enhances the survival of the mice. ${ }^{17)} \mathrm{MK}$ also improves heart function upon chronic heart failure after ischemic injury. ${ }^{143), 144)}$ Thus, in these diseases, MK itself is expected to be a potent therapeutic by promoting survival of damaged tissues (Table 3). MK produced by the yeast system is best suited for this purpose, since large scale production is possible and the yield of 
Table 3. MK as a target of therapeutics or a therapeutic

\begin{tabular}{|c|c|c|}
\hline Diseases and abnormalities & Phenotypes of MK KO mice & Animal experiments using therapeutics \\
\hline$\overline{\text { Restenosis }}$ & Horiba et al. $2000^{56)}$ & $\begin{array}{l}\text { Banno et al. } 2006^{137)} \text { (siRNA), } \\
\text { Hayashi et al. } 2005^{164)} \text { (AS oligoDNA) }\end{array}$ \\
\hline Rheumatoid arthritis & Maruyama et al. $2004^{13)}$ & Yamamoto et al. 2006 ${ }^{165)}$ (CSE, siRNA) \\
\hline Multiple screlosis & Wang et al. 2008 ${ }^{14)}$ & Wang et al. 2008 ${ }^{14)}$ (RNA aptamer) \\
\hline Adhesion after surgery & Inoh et al. $2004^{133)}$ & Yamamoto et al. 2006 ${ }^{165)}$ (siRNA) \\
\hline Nephritis & $\begin{array}{l}\text { Sato et al. } 2001,{ }^{9)} \\
\text { Kawai et al. } 2004,{ }^{134)} \\
\text { Kosugi et al. } 2006^{135)}\end{array}$ & Sato et al. 2005 ${ }^{136)}$ (AS oligoDNA) \\
\hline Hypertension & Hobo et al. $2009^{15)}$ & \\
\hline Malignant tumors & Salama et al. $2006^{123)}$ & $\begin{array}{l}\text { Takei et al. } 2001^{12)} \text { (AS oligoDNA), } \\
\text { Takei et al. } 2006^{122)} \text { (siRNA), } \\
\text { Dai et al. } 2009^{124)} \text { (AS oligoDNA) }\end{array}$ \\
\hline $\begin{array}{l}\text { Neuronal death } \\
\text { Retinal degeneration }\end{array}$ & Sakakima et al. 2009142) & $\begin{array}{l}\text { Yoshida et al. } 2001^{11)}(\mathrm{MK}) \\
\text { Unoki et al. } 1994^{16)}(\mathrm{MK})\end{array}$ \\
\hline Heart failure & Horiba et al. $2006^{17)}$ & $\begin{array}{l}\text { Horiba et al. } 2006^{17)}(\mathrm{MK}) \\
\text { Fukui et al. } 2008^{143)}(\mathrm{MK}), \\
\text { Takenaka et al. } 2009^{144)}(\mathrm{MK})\end{array}$ \\
\hline
\end{tabular}

Either an MK inhibitor or MK itself used as therapeutics was shown in the parenthesis. Disease was severer in MK KO mice when MK was used as therapeutics, and less severe when an MK inhibitor was used as therapeutics. AS, antisense; CSE, chondroitin sulfate E.

properly folded protein is high compared to production in bacteria.

MK is expressed in senile plaques in the brain of the patients. ${ }^{145)}$ Senile plaques are hallmark of the disease, and the primary deposit is amyloid $\beta$-peptide. In the brain of aged MK-deficient mice, plaque formation of amyloid $\beta$-peptide is more than in the brain of age-matched wild-type mice. Thus, MK expression in Alzheimer's disease might be induced to counteract the progression of the disease (Muramatsu, H. et al., unpublished observations). Indeed, MK inhibits cytotoxicity of amyloid $\beta$-peptide and its fibril formation. 146),147) MK expression is also markedly increased in the prefrontal cortex of chronic alcoholics, concomitant with shrinkage of the neural tissue. ${ }^{148)} \mathrm{MK}$ is probably synthesized to counteract the loss of neurons also in this case. In the rat hippocampus, chronic administration of morphine and yohimbine also upregulates MK expression. ${ }^{149)}$

\section{Conclusions and perspectives}

MK is involved in a variety of physiological and pathological processes. I expect that significant roles of MK will be further revealed even in fields not mentioned in this review. In this context, it is proper to mention that MK may be involved in protection against HIV infection, since the binding of HIV to nucleolin appears to be required for viral entry, and MK competes with HIV for nucleolin binding. ${ }^{150)}$

Our studies have shown that the MK receptor is a molecular complex containing proteoglycans. More studies are required to clarify all the components of the receptor complex and their mutual interactions. Essential roles of the MK family in development and reproduction have been established by severe phenotypes of mice doubly deficient in both MK and PTN. In depth analysis of MK single-knockout mice is expected to reveal new functions of MK, unshared with PTN.

Clinical application of MK inhibitors is much needed, especially for treatment of malignancy. The improvement in delivery methods of oligonucleotide reagents and development of low molecular weight inhibitors are among the subjects on which further basic research is required for the purpose.

\section{References}

1) Muramatsu, T. (2002) Midkine and pleiotrophin: two related proteins involved in development, survival, inflammation and tumorigenesis. J. Biochem. 132, 359-371. 
2) Muramatsu, T. (1993) Midkine (MK), the product of a retinoic acid responsive gene, and pleiotrophin constitute a new protein family regulating growth and differentiation. Int. J. Dev. Biol. 37, 183-188.

3) Kadomatsu, K. and Muramatsu, T. (2004) Midkine and pleiotrophin in neural development and cancer. Cancer Lett. 204, 127-143.

4) Deuel, T. F., Zhang, N., Yeh, H. J., Silos-Santiago, I. and Wang, Z. Y. (2002) Pleiotrophin: a cytokine with diverse functions and a novel signaling pathway. Arch. Biochem. Biophys. 397, 162-167.

5) Rauvala, H. and Peng, H. B. (1997) HB-GAM (heparin-binding growth-associated molecule) and heparin-type glycans in the development and placiticity of neuron-target contacts. Prog. Neurobiol. 52, 127-144.

6) Muramatsu, H., Shirahama, H., Yonezawa, S., Maruta, H. and Muramatsu, T. (1993) Midkine, a retinoic acid-inducible growth/differentiation factor: immunochemical evidence for the function and distribution. Dev. Biol. 159, 392-402.

7) Owada, K., Sanjo, N., Kobayashi, T., Mizusawa, H., Muramatsu, H., Muramatsu, T. et al. (1999) Midkine inhibits caspase-dependent apoptosis via the activation of mitogen-activated protein kinase and phosphatidylinositol 3-kinase in cultured neurons. J. Neurochem. 73, 2084-2092.

8) Maeda, N., Ichihara-Tanaka, K., Kimura, T., Kadomatsu, K., Muramatsu, T. and Noda, M. (1999) A receptor-like protein-tyrosine phosphatase $\mathrm{PTP} \zeta /$ RPTP $\beta$ binds a heparin-binding growth factor midkine. Involvement of arginine 78 of midkine in the high affinity binding to $\mathrm{PTP} \zeta$. J. Biol. Chem. 274, 12474-12479.

9) Sato, W., Kadomatsu, K., Yuzawa, Y., Muramatsu, H., Hotta, N., Matsuo, S. et al. (2001) Midkine is involved in neutrophil infiltration into the tubulointerstitium in ischemic renal injury. J. Immunol. 167, 3463-3469.

10) Muramatsu, H., Zou, P., Kurosawa, N., IchiharaTanaka, K., Maruyama, K., Inoh, K. et al. (2006) Female infertility in mice deficient in midkine and pleiotrophin, which form a distinct family of growth factors. Genes Cells 11, 1405-1417.

11) Yoshida, Y., Ikematsu, S., Moritoyo, T., Goto, M., Tsutsui, J., Sakuma, S. et al. (2001) Intraventricular administration of the neurotrophic factor midkine ameliorates hippocampal delayed neuronal death following transient forebrain ischemia in gerbils. Brain Res. 894, 46-55.

12) Takei, Y., Kadomatsu, K., Matsuo, S., Itoh, H., Nakazawa, K., Kubota, S. et al. (2001) Antisense oligodeoxynucleotide targeted to Midkine, a heparinbinding growth factor, suppresses tumorigenicity of mouse rectal carcinoma cells. Cancer Res. 61, 8486-8491.

13) Maruyama, K., Muramatsu, H., Ishiguro, N. and Muramatsu, T. (2004) Midkine, a heparin-binding growth factor, is fundamentally involved in the pathogenesis of rheumatoid arthritis. Arthritis Rheum. 50, 1420-1429.

14) Wang, J., Takeuchi, H., Sonobe, Y., Jin, S., Mizuno,
T., Miyakawa, S. et al. (2008) Inhibition of midkine alleviates experimental autoimmune encephalomyelitis through the expansion of regulatory $\mathrm{T}$ cell population. Proc. Natl. Acad. Sci. USA 105, 3915-3920.

15) Hobo, A., Yuzawa, Y., Kosugi, T., Kato, N., Asai, N., Sato, W. et al. (2009) The growth factor midkine regulates the renin-angiotensin system in mice. J. Clin. Invest. 119, 1616-1625.

16) Unoki, K., Ohba, N., Arimura, H., Muramatsu, H. and Muramatsu, T. (1994) Rescue of photoreceptors from the damaging effects of constant light by midkine, a retinoic acid-responsive gene product. Invest. Ophthalmol. Vis. Sci. 35, 4063-4068.

17) Horiba, M., Kadomatsu, K., Yasui, K., Lee, J. K., Takenaka, H., Sumida, A. et al. (2006) Midkine plays a protective role against cardiac ischemia/ reperfusion injury through a reduction of apoptotic reaction. Circulation 114, 1713-1720.

18) Kadomatsu, K., Tomomura, M. and Muramatsu, T. (1988) cDNA cloning and sequencing of a new gene intensely expressed in early differentiation stages of embryonal carcinoma cells and in midgestation period of mouse embryogenesis. Biochem. Biophys. Res. Commun. 151, 1312-1318.

19) Rauvala, H. (1989) An 18-kd heparin-binding protein of developing brain that is distinct from fibroblast growth factors. EMBO J. 8, 2933-2941.

20) Milner, P. G., Li, Y. S., Hoffman, R. M., Kodner, G. M., Siegel, N. R. and Deuel, T. F. (1989) A novel $17 \mathrm{kD}$ heparin-binding growth factor (HBGF-8) in bovine uterus: purification and N-terminal amino acid sequence. Biochem. Biophys. Res. Commun. 165, 1096-1103.

21) Tomomura, M., Kadomatsu, K., Matsubara, S. and Muramatsu, T. (1990) A retinoic acid-responsive gene, MK, found in the teratocarcinoma system. Heterogeneity of the transcript and the nature of the translation product. J. Biol. Chem. 265, 10765-10770.

22) Merenmies, J. and Rauvala, H. (1990) Molecular cloning of the $18-\mathrm{kDa}$ growth-associated protein of developing brain. J. Biol. Chem. 265, 1672116724.

23) Li, Y. S., Milner, P. G., Chauhan, A. K., Watson, M. A., Hoffman, R. M., Kodner, C. et al. (1990) Cloning and expression of a developmentally regulated protein that induces mitogenic and neurite outgrowth activity. Science 250, 1690-1694.

24) Kadomatsu, K., Huang, R. P., Suganuma, T., Murata, F. and Muramatsu, T. (1990) A retinoic acid responsive gene MK found in the teratocarcinoma system is expressed in spatially and temporally controlled manner during mouse embryogenesis. J. Cell Biol. 110, 607-616.

25) Tomomura, M., Kadomatsu, K., Nakamoto, M., Muramatsu, H., Kondoh, H., Imagawa, K. et al. (1990) A retinoic acid responsive gene, MK, produces a secreted protein with heparin binding activity. Biochem. Biophys. Res. Commun. 171, 603-609.

26) Muramatsu, T. (2000) Protein-bound carbohydrates 
on cell-surface as targets of recognition: an odyssey in understanding them. Glycoconj. J. 17, 577-595.

27) Tsutsui, J., Uehara, K., Kadomatsu, K., Matsubara, S. and Muramatsu, T. (1991) A new family of heparin-binding factors: strong conservation of midkine (MK) sequences between the human and the mouse. Biochem. Biophys. Res. Commun. 176, 792-797.

28) Englund, C., Birve, A., Falileeva, L., Grabbe, C. and Palmer, R. H. (2006) Miple1 and miple2 encode a family of MK/PTN homologues in Drosophila melanogaster. Dev. Genes Evol. 216, 10-18.

29) Fabri, L., Maruta, H., Muramatsu, H., Muramatsu, T., Simpson, R. J., Burgess, A. W. et al. (1993) Structural characterisation of native and recombinant forms of the neurotrophic cytokine MK. J. Chromatogr. 646, 213-225.

30) Muramatsu, H., Inui, T., Kimura, T., Sakakibara, S., Song, X. J., Maruta, H. et al. (1994) Localization of heparin-binding, neurite outgrowth and antigenic regions in midkine molecule. Biochem. Biophys. Res. Commun. 203, 1131-1139.

31) Kilpelainen, I., Kaksonen, M., Kinnunen, T., Avikainen, H., Fath, M., Linhardt, R. et al. (2000) Heparinbinding growth-associated molecule contains two heparin-binding $\beta$-sheet domains that are homologous to the thrombospondin type I repeat. J. Biol. Chem. 275, 13564-13570.

32) Iwasaki, W., Nagata, K., Hatanaka, H., Inui, T., Kimura, T., Muramatsu, T. et al. (1997) Solution structure of midkine, a new heparin-binding growth factor. EMBO J. 16, 6936-6946.

33) Asai, T., Watanabe, K., Ichihara-Tanaka, K., Kaneda, N., Kojima, S., Iguchi, A. et al. (1997) Identification of heparin-binding sites in midkine and their role in neurite-promotion. Biochem. Biophys. Res. Commun. 236, 66-70.

34) Akhter, S., Ichihara-Tanaka, K., Kojima, S., Muramatsu, H., Inui, T., Kimura, T. et al. (1998) Clusters of basic amino acids in midkine: roles in neurite-promoting activity and plasminogen activatorenhancing activity. J. Biochem. 123, 1127-1136.

35) Kojima, S., Inui, T., Muramatsu, H., Suzuki, Y., Kadomatsu, K., Yoshizawa, M. et al. (1997) Dimerization of midkine by tissue transglutaminase and its functional implication. J. Biol. Chem. 272, 9410-9416.

36) Muramatsu, H. and Muramatsu, T. (1991) Purification of recombinant midkine and examination of its biological activities: functional comparison of new heparin binding factors. Biochem. Biophys. Res. Commun. 177, 652-658.

37) Kaneda, N., Talukder, A. H., Nishiyama, H., Koizumi, S. and Muramatsu, T. (1996) Midkine, a heparin-binding growth/differentiation factor, exhibits nerve cell adhesion and guidance activity for neurite outgrowth in vitro. J. Biochem. 119, $1150-1156$.

38) Murasugi, A. and Tohma-Aiba, Y. (2003) Production of native recombinant human midkine in the yeast, Pichia pastoris. Protein Expr. Purif. 27, $244-252$
39) Take, M., Tsutsui, J., Obama, H., Ozawa, M., Nakayama, T. and Maruyama, I. (1994) Identification of nucleolin as a binding protein for midkine (MK) and heparin-binding growth associated molecule (HB-GAM). J. Biochem. 116, 1063-1068.

40) Inui, T., Bodi, J., Kubo, S., Nishio, H., Kimura, T., Kojima, S. et al. (1996) Solution synthesis of human midkine, a novel heparin-binding neurotrophic factor consisting of 121 amino acid residues with five disulphide bond. J. Pept. Sci. 2, 28-39.

41) Muramatsu, T., Muramatsu, H., Kaneda, N. and Sugahara, K. (2003) Recognition of glycosaminoglycans by midkine. Methods Enzymol. 363, 365-376.

42) Kaname, T., Kuwano, A., Murano, I., Uehara, K., Muramatsu, T. et al. (1993) Midkine gene (MDK), a gene for prenatal differentiation and neuroregulation, maps to band 11 p11.2 by fluorescence in situ hybridization. Genomics 17, 514-515.

43) Simon-Chazottes, D., Matsubara, S., Miyauchi, T., Muramatsu, T. and Guenet, J. L. (1992) Chromosomal localization of two cell surface-associated molecules of potential importance in development: midkine $(M d k)$ and basigin $(B s g)$. Mamm. Genome 2, 269-271.

44) Matsubara, S., Tomomura, M., Kadomatsu, K. and Muramatsu, T. (1990) Structure of a retinoic acidresponsive gene, MK, which is transiently activated during the differentiation of embryonal carcinoma cells and the mid-gestation period of mouse embryogenesis. J. Biol. Chem. 265, 9441-9443.

45) Uehara, K., Matsubara, S., Kadomatsu, K., Tsutsui, J. and Muramatsu, T. (1992) Genomic structure of human midkine (MK), a retinoic acid-responsive growth/differentiation factor. J. Biochem. 111, $563-567$.

46) Matsubara, S., Take, M., Pedraza, C. and Muramatsu, T. (1994) Mapping and characterization of a retinoic acid-responsive enhancer of midkine, a novel heparin-binding growth/differentiation factor with neurotrophic activity. J. Biochem. 115, 1088-1096.

47) Kaplan, F., Comber, J., Sladek, R., Hudson, T. J., Muglia, L. J., Macrae, T. et al. (2003) The growth factor midkine is modulated by both glucocorticoid and retinoid in fetal lung development. Am. J. Respir. Cell Mol. Biol. 28, 33-41.

48) Adachi, Y., Matsubara, S., Pedraza, C., Ozawa, M., Tsutsui, J., Takamatsu, H. et al. (1996) Midkine as a novel target gene for the Wilms' tumor suppressor gene (WT1). Oncogene 13, 2197-2203.

49) Reynolds, P. R., Mucenski, M. L., Le Cras, T. D., Nichols, W. C. and Whitsett, J. A. (2004) Midkine is regulated by hypoxia and causes pulmonary vascular remodeling. J. Biol. Chem. 279, 3712437132 .

50) Mitsiadis, T. A., Salmivirta, M., Muramatsu, T., Muramatsu, H., Rauvala, H., Lehtonen, E. et al. (1995) Expression of the heparin-binding cytokines, midkine (MK) and HB-GAM (pleiotrophin) is associated with epithelial-mesenchymal interactions during fetal development and organogenesis. Development 121, 37-51. 
51) Michikawa, M., Kikuchi, S., Muramatsu, H., Muramatsu, T. and Kim, S. U. (1993) Retinoic acid responsive gene product, midkine, has neurotrophic functions for mouse spinal cord and dorsal root ganglion neurons in culture. J. Neurosci. Res. 35, 530-539.

52) Kikuchi, S., Muramatsu, H., Muramatsu, T. and Kim, S. U. (1993) Midkine, a novel neurotrophic factor, promotes survival of mesencephalic neurons in culture. Neurosci Lett. 160, 9-12.

53) Satoh, J., Muramatsu, H., Moretto, G., Muramatsu, T., Chang, H. J., Kim, S. T. et al. (1993) Midkine that promotes survival of fetal human neurons is produced by fetal human astrocytes in culture. Brain Res. Dev. Brain Res. 75, 201-205.

54) Sumi, Y., Muramatsu, H., Takei, Y., Hata, K., Ueda, M. and Muramatsu, T. (2002) Midkine, a heparinbinding growth factor, promotes growth and glycosaminoglycan synthesis of endothelial cells through its action on smooth muscle cells in an artificial blood vessel model. J. Cell Sci. 115, 2659-2667.

55) Takada, T., Toriyama, K., Muramatsu, H., Song, X. J., Torii, S. and Muramatsu, T. (1997) Midkine, a retinoic acid-inducible heparin-binding cytokine in inflammatory responses: chemotactic activity to neutrophils and association with inflammatory synovitis. J. Biochem. 122, 453-458.

56) Horiba, M., Kadomatsu, K., Nakamura, E., Muramatsu, H., Ikematsu, S., Sakuma, S. et al. (2000) Neointima formation in a restenosis model is suppressed in midkine-deficient mice. J. Clin. Invest. 105, 489-495.

57) Qi, M., Ikematsu, S., Maeda, N., Ichihara-Tanaka, K., Sakuma, S., Noda, M. et al. (2001) Haptotactic migration induced by midkine. Involvement of protein-tyrosine phosphatase $\zeta$, mitogen-activated protein kinase, and phosphatidylinositol 3-kinase. J. Biol. Chem. 276, 15868-15875.

58) Zou, P., Muramatsu, H., Miyata, T. and Muramatsu, T. (2006) Midkine, a heparin-binding growth factor, is expressed in neural precursor cells and promotes their growth. J. Neurochem. 99, 1470-1479.

59) Kaneda, N., Talukder, A. H., Ishihara, M., Hara, S., Yoshida, K. and Muramatsu, T. (1996) Structural characteristics of heparin-line domain required for interaction of midkine with embryonic neurons. Biochem. Biophys. Res. Commun. 220, 108-112.

60) Ueoka, C., Kaneda, N., Okazaki, I., Nadanaka, S., Muramatsu, T. and Sugahara, K. (2000) Neuronal cell adhesion, mediated by the heparin-binding neuroregulatory factor midkine, is specifically inhibited by chondroitin sulfate E. Structural and functional implications of the over-sulfated chondroitin sulfate. J. Biol. Chem. 275, 37407-37413.

61) Zou, P., Zou, K., Muramatsu, H., Ichihara-Tanaka, K., Habuchi, O., Ohtake, S. et al. (2003) Glycosaminoglycan structures required for strong binding to midkine, a heparin-binding growth factor. Glycobiology 13, 35-42.

62) Kojima, T., Katsumi, A., Yamazaki, T., Muramatsu, T., Nagasaka, T., Ohsumi, K. et al. (1996) Human ryudocan from endothelium-like cells binds basic fibroblast growth factor, midkine, and tissue factor pathway inhibitor. J. Biol. Chem. 271, 5914-5920.

63) Nakanishi, T., Kadomatsu, K., Okamoto, T., IchiharaTanaka, K., Kojima, T., Saito, H. et al. (1997) Expression of syndecan-1 and -3 during embryogenesis of the central nervous system in relation to binding with midkine. J. Biochem. 121, 197-205.

64) Kurosawa, N., Chen, G. Y., Kadomatsu, K., Ikematsu, S., Sakuma, S. and Muramatsu, T. (2001) Glypican-2 binds to midkine: the role of glypican-2 in neuronal cell adhesion and neurite outgrowth. Glycoconj. J. 18, 499-507.

65) Zou, K., Muramatsu, H., Ikematsu, S., Sakuma, S., Salama, R. H., Shinomura, T. et al. (2000) A heparin-binding growth factor, midkine, binds to a chondroitin sulfate proteoglycan, PG-M/versican. Eur. J. Biochem. 267, 4046-4053.

66) Ichihara-Tanaka, K., Oohira, A., Rumsby, M. and Muramatsu, T. (2006) Neuroglycan C is a novel midkine receptor involved in process elongation of oligodendroglial precursor-like cells. J. Biol. Chem. 281, 30857-30864.

67) Muramatsu, H., Zou, K., Sakaguchi, N., Ikematsu, S., Sakuma, S. and Muramatsu, T. (2000) LDL receptor-related protein as a component of the midkine receptor. Biochem. Biophys. Res. Commun. 270, 936-941.

68) Muramatsu, H., Zou, P., Suzuki, H., Oda, Y., Chen, G. Y., Sakaguchi, N. et al. (2004) $\alpha_{4} \beta_{1^{-}}$and $\alpha_{6} \beta_{1^{-}}$ integrins are functional receptors for midkine, a heparin-binding growth factor. J. Cell Sci. 117, 5405-5415.

69) Polykratis, A., Katsoris, P., Courty, J. and Papadimitriou, E. (2005) Characterization of heparin affin regulatory peptide signaling in human endothelial cells. J. Biol. Chem. 280, 22454-22461.

70) Meng, K., Rodriguez-Pena, A., Dimitrov, T., Chen, W., Yamin, M., Noda, M. et al. (2000) Pleiotrophin signals increased tyrosine phosphorylation of $\beta$ catenin through inactivation of the intrinsic catalytic activity of the receptor-type protein tyrosine phosphatase $\beta / \zeta$. Proc. Natl. Acad. Sci. USA 97, 2603-2608.

71) Ohuchida, T., Okamoto, K., Akahane, K., Higure, A., Todoroki, H., Abe, Y. et al. (2004) Midkine protects hepatocellular carcinoma cells against TRAILmediated apoptosis through down-regulation of caspase-3 activity. Cancer 100, 2430-2436.

72) Huang, Y., Sook-Kim, M. and Ratovitski, E. (2008) Midkine promotes tetraspanin-integrin interaction and induces FAK-Stat1 $\alpha$ pathway contributing to migration/invasiveness of human head and neck squamous cell carcinoma cells. Biochem. Biophys. Res. Commun. 377, 474-478.

73) Cernkovich, E. R., Deng, J., Hua, K. and Harp, J. B. (2007) Midkine is an autocrine activator of signal transducer and activator of transcription 3 in 3T3L1 cells. Endocrinology 148, 1598-1604.

74) Huang, Y., Hoque, M. O., Wu, F., Trink, B., Sidransky, D. and Ratovitski, E. A. (2008) Midkine in- 
duces epithelial-mesenchymal transition through Notch2/Jak2-Stat3 signaling in human keratinocytes. Cell Cycle 7, 1613-1622.

75) Stoica, G. E., Kuo, A., Powers, C., Bowden, E. T., Sale, E. B., Riegel, A. T. et al. (2002) Midkine binds to anaplastic lymphoma kinase (ALK) and acts as a growth factor for different cell types. J. Biol. Chem. 277, 35990-35998.

76) Kuo, A. H., Stoica, G. E., Riegel, A. T. and Wellstein, A. (2007) Recruitment of insulin receptor substrate-1 and activation of NF- $\mathrm{NB}$ essential for midkine growth signaling through anaplastic lymphoma kinase. Oncogene 26, 859-869.

77) Shibata, Y., Muramatsu, T., Hirai, M., Inui, T., Kimura, T., Saito, H. et al. (2002) Nuclear targeting by the growth factor midkine. Mol. Cell. Biol. 22, 6788-6796.

78) Salama, R. H., Muramatsu, H., Zou, K., Inui, T., Kimura, T. and Muramatsu, T. (2001) Midkine binds to $37-\mathrm{kDa}$ laminin binding protein precursor, leading to nuclear transport of the complex. Exp. Cell Res. 270, 13-20.

79) Dai, L. C., Shao, J. Z., Min, L. S., Xiao, Y. T., Xiang, L. X. and Ma, Z. H. (2008) Midkine accumulated in nucleolus of HepG2 cells involved in rRNA transcription. World J. Gastroenterol. 14, 6249-6253.

80) Yokota, C., Takahashi, S., Eisaki, A., Asashima, M., Akhter, S., Muramatsu, T. et al. (1998) Midkine counteracts the activin signal in mesoderm induction and promotes neural formation. J. Biochem. 123, 339-346.

81) Schafer, M., Rembold, M., Wittbrodt, J., Schartl, M. and Winkler, C. (2005) Medial floor plate formation in zebrafish consists of two phases and requires trunk-derived Midkine-a. Genes Dev. 19, 897-902.

82) Liedtke, D. and Winkler, C. (2008) Midkine-b regulates cell specification at the neural plate border in zebrafish. Dev Dyn. 237, 62-74.

83) Matsumoto, K., Wanaka, A., Takatsuji, K., Muramatsu, H., Muramatsu, T. and Tohyama, M. (1994) A novel family of heparin-binding growth factors, pleiotrophin and midkine, is expressed in the developing rat cerebral cortex. Brain Res. Dev. Brain Res. 79, 229-241.

84) Sun, X. Z., Inouye, M., Fukui, Y., Hisano, S., Sawada, K., Muramatsu, H. et al. (1997) An immunohistochemical study of radial glial cells in the mouse brain prenatally exposed to gamma-irradiation. J. Neuropathol. Exp. Neurol. 56, 1339-1348.

85) Zhou, H., Muramatsu, T., Halfter, W., Tsim, K. W. and Peng, H. B. (1997) A role of midkine in the development of the neuromuscular junction. Mol. Cell. Neurosci. 10, 56-70.

86) Nakamura, E., Kadomatsu, K., Yuasa, S., Muramatsu, H., Mamiya, T., Nabeshima, T. et al. (1998) Disruption of the midkine gene $(M d k)$ resulted in altered expression of a calcium binding protein in the hippocampus of infant mice and their abnormal behaviour. Genes Cells 3, 811-822.

87) Ohgake, S., Shimizu, E., Hashimoto, K., Okamura,
N., Koike, K., Koizumi, H. et al. (2009) Dopaminergic hypofunctions and prepulse inhibition deficits in mice lacking midkine. Prog. Neuropsychopharmacol. Biol. Psychiatry 33, 541-546.

88) Zou, P., Muramatsu, H., Sone, M., Hayashi, H., Nakashima, T. and Muramatsu, T. (2006) Mice doubly deficient in the midkine and pleiotrophin genes exhibit deficits in the expression of $\beta$-tectorin gene and in auditory response. Lab. Invest. 86, 645-653.

89) Toriyama, K., Muramatsu, H., Hoshino, T., Torii, S. and Muramatsu, T. (1997) Evaluation of heparinbinding growth factors in rescuing morphogenesis of heparitinase-treated mouse embryonic lung explants. Differentiation 61, 161-167.

90) Mitsiadis, T. A., Muramatsu, T., Muramatsu, H. and Thesleff, I. (1995) Midkine (MK), a heparinbinding growth/differentiation factor, is regulated by retinoic acid and epithelial-mesenchymal interactions in the developing mouse tooth, and affects cell proliferation and morphogenesis. J. Cell Biol. 129, 267-281.

91) Ohta, S., Muramatsu, H., Senda, T., Zou, K., Iwata, H. and Muramatsu, T. (1999) Midkine is expressed during repair of bone fracture and promotes chondrogenesis. J. Bone Miner. Res. 14, 1132-1144.

92) Ikeda, S., Ichihara-Tanaka, K., Azuma, T., Muramatsu, T. and Yamada, M. (2000) Effects of midkine during in vitro maturation of bovine oocytes on subsequent developmental competence. Biol. Reprod. 63, 1067-1074.

93) Ikeda, S., Saeki, K., Imai, H. and Yamada, M. (2006) Abilities of cumulus and granulosa cells to enhance the developmental competence of bovine oocytes during in vitro maturation period are promoted by midkine; a possible implication of its apoptosis suppressing effects. Reproduction 132, 549-557.

94) Tsutsui, J., Kadomatsu, K., Matsubara, S., Nakagawara, A., Hamanoue, M., Takao, S. et al. (1993) A new family of heparin-binding growth/differentiation factors: increased midkine expression in Wilms' tumor and other human carcinomas. Cancer Res. 53, 1281-1285.

95) Aridome, K., Tsutsui, J., Takao, S., Kadomatsu, K., Ozawa, M., Aikou, T. et al. (1995) Increased midkine gene expression in human gastrointestinal cancers. Jpn. J. Cancer Res. 86, 655-661.

96) Garver, R. I., Jr., Chan, C. S. and Milner, P. G. (1993) Reciprocal expression of pleiotrophin and midkine in normal versus malignant lung tissues. Am. J. Respir. Cell Mol. Biol. 9, 463-466.

97) O'Brien, T., Cranston, D., Fuggle, S., Bicknell, R. and Harris, A. L. (1996) The angiogenic factor midkine is expressed in bladder cancer, and overexpression correlates with a poor outcome in patients with invasive cancers. Cancer Res. 56, 2515-2518.

98) Konishi, N., Nakamura, M., Nakaoka, S., Hiasa, Y., Cho, M., Uemura, H. et al. (1999) Immunohistochemical analysis of midkine expression in human prostate carcinoma. Oncology 57, 253-257.

99) Nakagawara, A., Milbrandt, J., Muramatsu, T. Deuel, T. F., Zhao, H., Cnaan, A. et al. (1995) 
Differential expression of pleiotrophin and midkine in advanced neuroblastomas. Cancer Res. 55, 1792-1797.

100) Mishima, K., Asai, A., Kadomatsu, K., Ino, Y., Nomura, K., Narita, Y. et al. (1997) Increased expression of midkine during the progression of human astrocytomas. Neurosci. Lett. 233, 29-32.

101) Kadomatsu, K., Hagihara, M., Akhter, S., Fan, Q. W., Muramatsu, H. and Muramatsu, T. (1997) Midkine induces the transformation of NIH3T3 cells. Br. J. Cancer 75, 354-359.

102) Kang, H. C., Kim, I. J., Park, J. H., Shin, Y., Ku, J. L., Jung, M. S. et al. (2004) Identification of genes with differential expression in acquired drugresistant gastric cancer cells using high-density oligonucleotide microarrays. Clin. Cancer Res. 10, 272-284.

103) Mirkin, B. L., Clark, S., Zheng, X., Chu, F., White, B. D., Greene, M. et al. (2005) Identification of midkine as a mediator for intercellular transfer of drug resistance. Oncogene 24, 4965-4974.

104) Mashima, T., Sato, S., Sugimoto, Y., Tsuruo, T. and Seimiya, H. (2009) Promotion of glioma cell survival by acyl-CoA synthetase 5 under extracellular acidosis conditions. Oncogene 28, 9-19.

105) Mashour, G. A., Ratner, N., Khan, G. A., Wang, H. L., Martuza, R. L. and Kurtz, A. (2001) The angiogenic factor midkine is aberrantly expressed in NF1-deficient Schwann cells and is a mitogen for neurofibroma-derived cells. Oncogene 20, 97-105.

106) Muramatsu, H., Song, X. J., Koide, N., Hada, H., Tsuji, T., Kadomatsu, K. et al. (1996) Enzymelinked immunoassay for midkine, and its application to evaluation of midkine levels in developing mouse brain and sera from patients with hepatocellular carcinomas. J. Biochem. 119, 1171-1175.

107) Ikematsu, S., Yano, A., Aridome, K., Kikuchi, M., Kumai, H., Nagano, H. et al. (2000) Serum midkine levels are increased in patients with various types of carcinomas. Br. J. Cancer 83, 701-706.

108) Muramatsu, T. and Muramatsu, H. (2008) Glycosaminoglycan-binding cytokines as tumor markers. Proteomics 8, 3350-3359.

109) Salama, R. H., Muramatsu, H., Shimizu, E., Hashimoto, K., Ohgake, S., Watanabe, H. et al. (2005) Increased midkine levels in sera from patients with Alzheimer's disease. Prog. Neuropsychopharmacol. Biol. Psychiatry 29, 611-616.

110) Song, X-J., Muramatsu, H., Aridome, K., Aikou, T., Koide, N., Tsuji, T. et al. (1997) The serum level of midkine, a heparin-binding growth factor, as a tumor marker. Biomed. Res. 18, 375-381.

111) Shimada, H., Nabeya, Y., Tagawa, M., Okazumi, S., Matsubara, H., Kadomatsu, K. et al. (2003) Preoperative serum midkine concentration is a prognostic marker for esophageal squamous cell carcinoma. Cancer Sci. 94, 628-632.

112) Jia, H. L., Ye, Q. H., Qin, L. X., Budhu, A., Forgues, M., Chen, Y. et al. (2007) Gene expression profiling reveals potential biomarkers of human hepatocellular carcinoma. Clin. Cancer Res. 13, 1133-1139.

113) Salama, R. M. H., Muramatsu, H., Kobayashi, H., Nomura, S., Mizutani, S. and Muramatsu, T.
(2006) Serum levels of midkine, a heparin-binding growth factor increase in both malignant and benign gynecological tumor. Reprod. Immunol. Biol. 21, 64-70.

114) Ikematsu, S., Nakagawara, A., Nakamura, Y. Sakuma, S., Wakai, K., Muramatsu, T. et al. (2003) Correlation of elevated level of blood midkine with poor prognostic factors of human neuroblastoma. Br. J. Cancer 88, 1522-1526.

115) Ikematsu, S., Nakagawara, A., Nakamura, Y., Ohira, M., Shinjo, M., Kishida, S. et al. (2008) Plasma midkine level is a prognostic factor for human neuroblastoma. Cancer Sci. 99, 2070-2074.

116) Ibusuki, M., Fujimori, H., Yamamoto, Y., Ota, K. Ueda, M., Shinriki, S. et al. (2009) Midkine in plasma as a novel breast cancer marker. Cancer Sci. 100, 1735-1739.

117) Kaname, T., Kadomatsu, K., Aridome, K., Yamashita, S., Sakamoto, K., Ogawa, M. et al. (1996) The expression of truncated MK in human tumors. Biochem. Biophys. Res. Commun. 219, 256-260.

118) Miyashiro, I., Kaname, T., Shin, E., Wakasugi, E. Monden, T., Takatsuka, Y. et al. (1997) Midkine expression in human breast cancers: expression of truncated form. Breast Cancer Res. Treat. 43, 1-6.

119) Aridome, K., Takao, S., Kaname, T., Kadomatsu, K., Natsugoe, S., Kijima, F. et al. (1998) Truncated midkine as a marker of diagnosis and detection of nodal metastases in gastrointestinal carcinomas. Br. J. Cancer 78, 472-477.

120) Paul, S., Mitsumoto, T., Asano, Y., Kato, S., Kato, M. and Shinozawa, T. (2001) Detection of truncated midkine in Wilms' tumor by a monoclonal antibody against human recombinant truncated midkine. Cancer Lett. 163, 245-251.

121) Nobata, S., Shinozawa, T. and Sakanishi, A. (2005) Truncated midkine induces transformation of cultured cells and short latency of tumorigenesis in nude mice. Cancer Lett. 219, 83-89.

122) Takei, Y., Kadomatsu, K., Goto, T. and Muramatsu, T. (2006) Combinational antitumor effect of siRNA against midkine and paclitaxel on growth of human prostate cancer xenografts. Cancer 107 864-873.

123) Salama, R. H., Muramatsu, H., Zou, P., Okayama, M. and Muramatsu, T. (2006) Midkine, a heparinbinding growth factor, produced by the host enhances metastasis of Lewis lung carcinoma cells. Cancer Lett. 233, 16-20.

124) Dai, L. C., Yao, X., Wang, X., Niu, S. Q., Zhou, L. F., Fu, F. F. et al. (2009) In vitro and in vivo suppression of hepatocellular carcinoma growth by midkine-antisense oligonucleotide-loaded nanoparticles. World J. Gastroenterol. 15, 1966-1972.

125) Maehara, H., Kaname, T., Yanagi, K., Hanzawa, H., Owan, I., Kinjou, T. et al. (2007) Midkine as a novel target for antibody therapy in osteosarcoma. Biochem. Biophys. Res. Commun. 358, 757-762.

126) Chen, S., Bu, G., Takei, Y., Sakamoto, K., Ikematsu, S., Muramatsu, T. et al. (2007) Midkine and LDL-receptor-related protein 1 contribute to the anchorage-independent cell growth of cancer cells. J. Cell. Sci. 120, 4009-4015. 
127) Adachi, Y., Reynolds, P. N., Yamamoto, M., Grizzle, W. E., Overturf, K., Matsubara, S. et al. (2000) Midkine promoter-based adenoviral vector gene delivery for pediatric solid tumors. Cancer Res. 60, 4305-4310.

128) Adachi, Y., Reynolds, P. N., Yamamoto, M., Wang, M., Takayama, K., Matsubara, S. et al. (2001) A midkine promoter-based conditionally replicative adenovirus for treatment of pediatric solid tumors and bone marrow tumor purging. Cancer Res. 61, $7882-7888$.

129) Tomizawa, M., Yu, L., Wada, A., Tamaoki, T., Kadomatsu, K., Muramatsu, T. et al. (2003) A promoter region of the midkine gene that is frequently expressed in human hepatocellular carcinoma can activate a suicide gene as effectively as the $\alpha$ fetoprotein promoter. Br. J. Cancer 89, 1086-1090.

130) Yu, L., Yamamoto, N., Kadomatsu, K., Muramatsu, T., Matsubara, S., Sakiyama, S. et al. (2004) Midkine promoter can mediate transcriptional activation of a fused suicide gene in a broader range of human breast cancer compared with c-erbB-2 promoter. Oncology 66, 143-149.

131) Yoshida, Y., Goto, M., Tsutsui, J., Ozawa, M., Sato, E., Osame, M. et al. (1995) Midkine is present on the early stage of cerebral infarct. Dev. Brain Res. 85, 25-30.

132) Ochiai, K., Muramatsu, H., Yamamoto, S., Ando, H. and Muramatsu, T. (2004) The role of midkine and pleiotrophin in liver regeneration. Liver Int. 24, 484-491.

133) Inoh, K., Muramatsu, H., Ochiai, K., Torii, S. and Muramatsu, T. (2004) Midkine, a heparin-binding cytokine, plays key roles in intraperitoneal adhesions. Biochem. Biophys. Res. Commun. 317, 108113.

134) Kawai, H., Sato, W., Yuzawa, Y., Kosugi, T., Matsuo, S., Takei, Y. et al. (2004) Lack of the growth factor midkine enhances survival against cisplatin-induced renal damage. Am. J. Pathol. 165, 1603-1612.

135) Kosugi, T., Yuzawa, Y., Sato, W., Kawai, H., Matsuo, S., Takei, Y. et al. (2006) Growth factor midkine is involved in the pathogenesis of diabetic nephropathy. Am. J. Pathol. 168, 9-19.

136) Sato, W., Takei, Y., Yuzawa, Y., Matsuo, S., Kadomatsu, K. and Muramatsu, T. (2005) Midkine antisense oligodeoxyribonucleotide inhibits renal damage induced by ischemic reperfusion. Kidney Int. 67, 1330-1339.

137) Banno, H., Takei, Y., Muramatsu, T., Komori, K. and Kadomatsu, K. (2006) Controlled release of small interfering RNA targeting midkine attenuates intimal hyperplasia in vein grafts. J. Vasc. Surg. 44, 633-641.

138) Hirota, Y., Osuga, Y., Koga, K., Yoshino, O., Hirata, T., Harada, M. et al. (2005) Possible implication of midkine in the development of endometriosis. Hum. Reprod. 20, 1084-1089.

139) Ezquerra, L., Herradon, G., Nguyen, T., SilosSantiago, I. and Deuel, T. F. (2005) Midkine, a newly discovered regulator of the renin-angiotensin pathway in mouse aorta: significance of the pleiotrophin/midkine developmental gene family in angiotensin II signaling. Biochem. Biophys. Res. Commun. 333, 636-643.

140) Ezquerra, L., Herradon, G., Nguyen, T., SilosSantiago, I. and Deuel, T. F. (2006) Midkine is a potent regulator of the catecholamine biosynthesis pathway in mouse aorta. Life Sci. 79, 1049-1055.

141) Takada, J., Ooboshi, H., Ago, T., Kitazono, T., Yao, H., Kadomatsu, K. et al. (2005) Postischemic gene transfer of midkine, a neurotrophic factor, protects against focal brain ischemia. Gene Ther. 12, 487493.

142) Sakakima, H., Yoshida, Y., Yamazaki, Y., Matsuda, F., Ikutomo, M., Ijiri, K. et al. (2009) Disruption of the midkine gene (Mdk) delays degeneration and regeneration in injured peripheral nerve. J. Neurosci. Res. 87, 2908-2915.

143) Fukui, S., Kitagawa-Sakakida, S., Kawamata, S. Matsumiya, G., Kawaguchi, N., Matsuura, N. et al. (2008) Therapeutic effect of midkine on cardiac remodeling in infarcted rat hearts. Ann. Thorac. Surg. 85, 562-570.

144) Takenaka, H., Horiba, M., Ishiguro, H., Sumida, A., Hojo, M., Usui, A. et al. (2009) Midkine prevents ventricular remodeling and improves long-term survival after myocardial infarction. Am. J. Physiol. Heart Circ. Physiol. 296, H462-469.

145) Yasuhara, O., Muramatsu, H., Kim, S. U., Muramatsu, T., Maruta, H. and McGeer, P. L. (1993) Midkine, a novel neurotrophic factor, is present in senile plaques of Alzheimer disease. Biochem. Biophys. Res. Commun. 192, 246-251.

146) Yu, G. S., Hu, J. and Nakagawa, H. (1998) Inhibition of $\beta$-amyloid cytotoxicity by midkine. Neurosci. Lett. 254, 125-128.

147) Monji, A., Yoshida, I., Tashiro, K., Hayashi, Y., Matsuda, K. and Tashiro, N. (2000) Inhibition of $\mathrm{A} \beta$ fibril formation and $\mathrm{A} \beta$-induced cytotoxicity by senile plaque-associated proteins. Neurosci. Lett. 278, 81-84.

148) Flatscher-Bader, T. and Wilce, P. A. (2008) Impact of alcohol abuse on protein expression of midkine and excitatory amino acid transporter 1 in the human prefrontal cortex. Alcohol Clin. Exp. Res. 32, 1849-1858.

149) Ezquerra, L., Perez-Garcia, C., Garrido, E., DiezFernandez, C., Deuel, T. F., Alguacil, L. F. et al. (2007) Morphine and yohimbine regulate midkine gene expression in the rat hippocampus. Eur. J. Pharmacol. 557, 147-150.

150) Callebaut, C., Nisole, S., Briand, J. P., Krust, B. and Hovanessian, A. G. (2001) Inhibition of HIV infection by the cytokine midkine. Virology 281, 248264.

151) Inazumi, T., Tajima, S., Nishikawa, T., Kadomatsu, K., Muramatsu, H. and Muramatsu, T. (1997) Expression of the retinoid-inducible polypeptide, midkine, in human epidermal keratinocytes. Arch. Dermatol. Res. 289, 471-475.

152) Sumi, Y., Muramatsu, H., Hata, K., Ueda, M. and Muramatsu, T. (2000) Midkine enhances early 
stages of collagen gel contraction. J. Biochem. 127, $247-251$

153) Yamada, H., Inazumi, T., Tajima, S., Muramatsu, H. and Muramatsu, T. (1997) Stimulation of collagen expression and glycosaminoglycan synthesis by midkine in human skin fibroblasts. Arch. Dermatol. Res. 289, 429-433.

154) Kojima, S., Muramatsu, H., Amanuma, H. and Muramatsu, T. (1995) Midkine enhances fibrinolytic activity of bovine endothelial cells. J. Biol. Chem. 270, 9590-9596.

155) Ruan, M., Ji, T., Wu, Z., Zhou, J. and Zhang, C. (2007) Evaluation of expression of midkine in oral squamous cell carcinoma and its correlation with tumour angiogenesis. Int. J. Oral Maxillofac. Surg. 36, 159-164.

156) Maeda, S., Shinchi, H., Kurahara, H., Mataki, Y., Noma, H., Maemura, K. et al. (2007) Clinical significance of midkine expression in pancreatic head carcinoma. Br. J. Cancer 97, 405-411.

157) Garver, R. I., Jr., Radford, D. M., Donis-Keller, H., Wick, M. R. and Milner, P. G. (1994) Midkine and pleiotrophin expression in normal and malignant breast tissue. Cancer 74, 1584-1590.

158) Moon, H. S., Park, W. I., Sung, S. H., Choi, E. A., Chung, H. W. and Woo, B. H. (2003) Immunohistochemical and quantitative competitive PCR analyses of midkine and pleiotrophin expression in cervical cancer. Gynecol. Oncol. 88, 289-297.

159) Tanabe, K., Matsumoto, M., Ikematsu, S., Nagase, S., Hatakeyama, A., Takano, T. et al. (2008) Midkine and its clinical significance in endometrial carcinoma. Cancer Sci. 99, 1125-1130.
160) Nakanishi, T., Kadomatsu, K., Okamoto, T., Tomoda, Y. and Muramatsu, T. (1997) Expression of midkine and pleiotropin in ovarian tumors. Obstet. Gynecol. 90, 285-290.

161) Jin, Z., Lahat, G., Korchin, B., Nguyen, T., Zhu, Q. S., Wang, X. et al. (2008) Midkine enhances softtissue sarcoma growth: a possible novel therapeutic target. Clin Cancer Res. 14, 5033-5042.

162) Tong, Y., Mentlein, R., Buhl, R., Hugo, H. H., Krause, J., Mehdorn, H. M. et al. (2007) Overexpression of midkine contributes to anti-apoptotic effects in human meningiomas. J. Neurochem. 100, 1097-1107.

163) Hidaka, H., Yagasaki, H., Takahashi, Y., Hama, A., Nishio, N., Tanaka, M. et al. (2007) Increased midkine gene expression in childhood B-precursor acute lymphoblastic leukemia. Leuk. Res. 31, 10451051.

164) Hayashi, K., Banno, H., Kadomatsu, K., Takei, Y., Komori, K. and Muramatsu, T. (2005) Antisense oligodeoxyribonucleotide as to the growth factor midkine suppresses neointima formation induced by balloon injury. Am. J. Physiol. Heart Circ. Physiol. 288, H2203-H2209.

165) Yamamoto, H., Muramatsu, H., Nakanishi, T., Natori, Y., Sakuma, S., Ishiguro, N. et al. (2006) Midkine as a molecular target: comparison of effects of chondroitin sulfate $\mathrm{E}$ and siRNA. Biochem. Biophys. Res. Commun. 351, 915-919.

(Received Nov. 25, 2009; accepted Feb. 24, 2010)

\section{Profile}

Takashi Muramatsu graduated from The University of Tokyo in 1963 and received his Ph.D. from The University of Tokyo in 1968. He was Research Fellow, Department of Microbiology and Immunology, Albert Einstein College of Medicine (1968-1972), Assistant Professor, Department of Biochemistry, Kobe University School of Medicine (1972-1973), Associate Professor, Department of Biochemistry, Kobe University School of Medicine (1973-1980), Visiting Scientist, Department of Molecular Biology, Pasteur Institute (1977-1978), Professor, Department of Biochemistry, Kagoshima University Faculty of Medicine (1980-1993), Professor, Department of Biochemistry, Nagoya University School of Medicine (1993-2000) and Professor and Chairman, Department of Biological Chemistry, Nagoya University

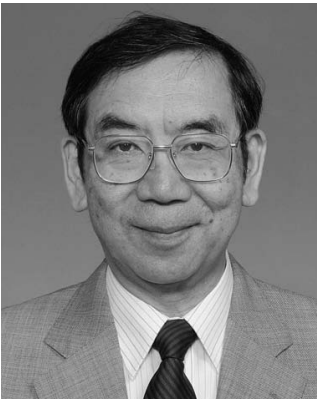
Graduate School of Medicine (2000-2004). Since 2004, he has been Professor, Department of Health Science, Faculty of Psychological and Physical Science, Aichi Gakuin University and Professor Emeritus, Nagoya University. He served as Associate Editor, Glycobiology (1999-2007) and President, Japanese Biochemical Society (2002-2003). He received Young Investigator's Award from Japanese Biochemical Society for research into glycosidases acting on glycoconjugates (1975) and Chunichi Cultural Prize for the discovery of midkine (2002). His major contributions are discovery and application of endoglycosidases acting on glycoproteins, discovery of embryoglycan, discovery and elucidation of function of basigin, discovery and elucidation of physiological and pathological roles of midkine, and molecular cloning and manipulation of $N$-acetylglucosamine 6-sulfotransferase-1. 